\title{
Role of IL-12p40 in cervical carcinoma
}

\author{
HJMAA Zijlmans', S Punt'², GJ Fleuren², JB Trimbos ${ }^{3}$, GG Kenter' and A Gorter ${ }^{*, 2}$ \\ 'Department of Gynecology, The Netherlands Cancer Institute Antoni van Leeuwenhoek Hospital, Plesmanlaan 121, I066CX, Amsterdam, \\ The Netherlands; ${ }^{2}$ Department of Pathology, Leiden University Medical Center, 2300 RC Leiden, The Netherlands; ${ }^{3}$ Department of Gynecology, \\ Leiden University Medical Center, 2300 RC Leiden, The Netherlands
}

BACKGROUND: Previously, we have shown that low IL-I 2p40 mRNA expression by cervical cancer cells is associated with a poor survival of cervical cancer patients. As IL- I 2p40 is both a subcomponent of interleukin (IL)- I 2 and IL-23, the aim of this study was to elucidate the role of IL- $12 p 40$ in cervical cancer.

METHODS: We have measured the expression of IL-23p/9 mRNA, IL-I2p35 mRNA and IL-I2p40 mRNA using mRNA in situ hybridisation. The IL-I and IL-6 were measured by immunohistochemistry.

RESULTS: As IL-23 is a component of the IL- I 7/IL-23 pathway, a pathway induced by IL-I and IL-6 in humans, we have studied IL- I and IL-6 expression. Only a high number of stromal IL-6-positive cells was shown to associate with poor disease-specific survival. The worst disease-specific survival was associated with a subgroup of patients that displayed a high number of IL-6-positive cells and low IL-I 2p40 expression $(P<0.00 I)$. Both a high number of IL-6-positive cells and a high number of IL-6-positive cells, plus low IL-I 2p40 expression were shown to be clinicopathological parameters independent of lymph node metastasis, parametrial involvement and Sedlis score $(P=0.009$ and $P=0.007$, respectively).

CONCLUSION: Our results with IL-6 and IL- I 2p40 are in accordance with the hypothesis that the IL- I 7/IL-23 pathway has a suppressive role in cervical cancer.

British Journal of Cancer (2012) 1 07, 1956-1962. doi:I0.1038/bjc.2012.488 www.bjcancer.com

Published online 25 October 2012

(c) 2012 Cancer Research UK

Keywords: cervical cancer; IL-6; IL-I 2p40

Cervical cancer is a leading cause of morbidity and mortality among women worldwide, especially in the developing countries (Munoz, 2000; Rock et al, 2000). Infection with oncogenic types of human papillomavirus (HPV) is an important factor in the development of cervical cancer (Schwartz et al, 2001; Waggoner, 2003). The persistent HPV infection induces an inflammatory response. Inflammation is an important component in the majority of tumour types. The outcome of this inflammatory response surrounding the cancer cells is dependent on the composition of the inflammatory infiltrate and locally produced signalling molecules (Coussens and Werb, 2002). Although inflammatory cells within the neoplastic lesion are capable of generating an anti-tumour response, this does not efficiently occur (Elgert et al, 1998; Manna and Mohanakumar, 2002).

Inflammatory cells are attracted to the tumour site by locally produced cytokines and chemokines (Balkwill, 2003; Vicari et al, 2004). Cervical cancer cells are known to produce an extensive range of cytokines and chemokines, such as CCL2, GM-CSF, TNF $\alpha$ and interleukin (IL)-12 (Clerici et al, 1997; Hazelbag et al, 2001; Zijlmans et al, 2006). In addition to attracting inflammatory cells, these cytokines and chemokines influence the activation status and function of infiltrating antigen-presenting cells and stromal cells, thus influencing the course of the disease (Kusmartsev and Gabrilovich, 2002; Balkwill, 2003).

*Correspondence: Dr A Gorter; E-mail: A.Gorter@lumc.nl Received 20 June 2012; revised 3 October 2012; accepted 5 October 2012; published online 25 October 2012
In a previous study, we have shown that high expression levels or undetectable levels of $I L-12 p 40$ mRNA in cervical carcinoma are associated with an improved overall survival compared with low amounts of $I L-12 p 40$ that were associated with poor survival (Zijlmans et al, 2007). As IL-12 is known to stimulate effector cell populations, such as cytotoxic T cells and natural killer cells (Strobl, 2003; Trinchieri, 2003), our results suggest a dual role for $I L-12 p 40$.

The IL-12 cytokine family includes IL-12, IL-23, IL-27 and IL-35 (Xu et al, 2010). From this family, IL-12 and IL-23 share the IL-12p40 subchain. Interleukin-12 is composed of IL-12p40 and IL-12p35, whereas IL-23 is composed of IL-12p40 and IL-23p19. Interleukin-23 has, amongst others, an important role in the IL-17/ IL-23 pathway, resulting in the maintenance and expansion of Th17 cells (Korn et al, 2009). In addition to IL-23, IL-1 and IL-6 are thought to have an important role in the induction of Th17 cells in humans (Acosta-Rodriguez et al, 2007). The effect of IL-23 on cancer progression or cancer eradication is still not clear (Langowski et al, 2006; Shan et al, 2006).

To further delineate the role of IL-12p40 in cervical carcinoma, we have quantified the mRNA expression levels of $I L-23 p 19$, and compared its expression level with $I L-12 p 35$ and $I L-12 p 40$ to investigate the relative importance of IL-12 and IL-23 in the tumour microenvironment. In addition, we have investigated the role of IL-1 and IL- 6 in the tumour microenvironment by determining both the number of IL-1-positive cells and the number of IL-6-positive cells. Finally, we have assessed the association between IL-23p19, IL-12p35, IL-12p40, high number of IL-6-positive cells and clinicopathological parameters. 


\section{MATERIAL AND METHODS}

\section{Patient material}

Between 1985 and 1995, 254 untreated patients suffering from primary cervical carcinoma with stage IB and IIA underwent a radical hysterectomy type III with lymphadenectomy. From the tissue obtained, based on the availability of the material, 90 tissue samples were accessible for research. Tissues were routinely embedded in paraffin after $10 \%$ formalin fixation. The tissue samples of each patient were examined by a pathologist for the presence of tumour. Tumour percentage varied between $20 \%$ and $90 \%$, with median $60 \%$. The characteristics of the patients are depicted in Table 1. Forty-seven patients received post-operative radiotherapy because of either tumour-positive lymph nodes or the presence of positive risk factors described by the Sedlis criteria (Sedlis et al, 1999; a combination of two of the following unfavourable prognostic parameters: depth of infiltration $\geqslant 15 \mathrm{~mm}$ (deep stromal invasion; middle or deep third), tumour size $\geqslant 40 \mathrm{~mm}$ and presence of vasoinvasion). Human tissue samples were used according to the guidelines of the Ethical Committee of the Leiden University Medical Centre.

\section{Preparation of $I L-23 p 19, I L-12 p 35$ and $I L-12 p 40$ probes}

RNA was isolated from frozen human spleen using TRIzol (Invitrogen, Breda, The Netherlands) and first-strand cDNA was synthesised with oligoDT primers and Reverse Transcriptase AMV (both from Roche Diagnostics GmbH, Mannheim, Germany), both according to manufacturer's instructions. Oligonucleotide primers for $I L-23-p 19, I L-12 p 35$ and $I L-12 p 40$ were chosen on the basis of known sequences (see Table 2), and cDNA encoding for the different cytokines was amplified. A pGEM-3Zf $(+)$ Vector (Promega, Madison, WI, USA) was linearised with SmaI and the PCR products were cloned into the vector. After transferring the

Table I Summary of clinicopathological features of patients and tumours

\begin{tabular}{|c|c|c|}
\hline Patient and tumour characteristics & Outcome & $N^{a}$ \\
\hline Age & $\begin{array}{l}45 \text { (mean) } \\
29-76 \text { (range) }\end{array}$ & 90 \\
\hline $\mathrm{FIGO}^{\mathrm{b}}$ stage & $\begin{array}{l}\text { IB } \\
\| A\end{array}$ & $\begin{array}{l}68 \\
21\end{array}$ \\
\hline Lymph node metastasis & $\begin{array}{l}\text { No } \\
\text { Yes }\end{array}$ & $\begin{array}{l}66 \\
22\end{array}$ \\
\hline Tumour size & $\begin{array}{l}<40 \mathrm{~mm} \\
\geqslant 40 \mathrm{~mm}\end{array}$ & $\begin{array}{l}37 \\
26\end{array}$ \\
\hline Depth of infiltration ${ }^{b}$ & $\begin{array}{l}<15 \mathrm{~mm} \\
\geqslant 15 \mathrm{~mm}\end{array}$ & $\begin{array}{l}58 \\
26\end{array}$ \\
\hline Vascular space involvement ${ }^{\mathrm{b}}$ & $\begin{array}{l}\text { No } \\
\text { Yes }\end{array}$ & $\begin{array}{l}39 \\
47\end{array}$ \\
\hline Sedlis criteriac ${ }^{c}$ & $\begin{array}{l}\text { Positive } \\
\text { Negative }\end{array}$ & $\begin{array}{l}28 \\
52\end{array}$ \\
\hline Parametrial invasion ${ }^{\mathrm{b}}$ & $\begin{array}{l}\text { No } \\
\text { Yes }\end{array}$ & $\begin{array}{l}74 \\
14\end{array}$ \\
\hline HPV status $^{\mathrm{d}}$ & $\begin{array}{l}16,18 \\
\text { Others }\end{array}$ & $\begin{array}{l}66 \\
15\end{array}$ \\
\hline Histology & $\begin{array}{l}\text { Squamous } \\
\text { Adenosquamous } \\
\text { Adeno } \\
\text { Others }\end{array}$ & $\begin{array}{r}58 \\
18 \\
7 \\
6\end{array}$ \\
\hline
\end{tabular}

Abbreviations: $\mathrm{FIGO}=$ International Federation of Gynecology and Obstetrics; HPV = human papillomavirus. ${ }^{a} \mathrm{~N}$ is the number of patients/cervical carcinomas. ${ }^{\text {b }}$ The number of reported cases is affected by incidental missing cases. 'Sedlis criteria (Sedlis et al, 1999): a combination of two of the following unfavourable prognostic parameters: depth of infiltration $\geqslant 15 \mathrm{~mm}$ (deep stromal invasion; middle or deep third), tumour size $\geqslant 40 \mathrm{~mm}$ and presence of vasoinvasion. ${ }^{\mathrm{D}}$ Only data for cervical carcinoma samples with a determined HPV type were included. Other subtypes included HPV3I $(n=2), \operatorname{HPV} 33(n=6)$, HPV35 $(n=1), \operatorname{HPV} 45(n=3), \operatorname{HPV} 58(n=1), \operatorname{HPV} 59(n=2)$ and HPV68 $(n=1)$. vector to E. coli strain Top 10 (Invitrogen Corp., San Diego, CA, USA), the plasmids were isolated by using the QIAfilter Maxi KITS protocol (QIAGEN GmbH, Hilden, Germany). The sequence of the PCR product was confirmed by DNA sequencing. Plasmids were linearised with $B a m \mathrm{H} 1$ and EcoR1 (both from Boehringer, Mannheim, Germany) in case of $I L-12 p 40$, with BamH1 and SacI in case of $I L-12 p 35$ and with SacII, SalI and SpeI (Boehringer) in case of $I L-23 p 19$, using One-Phor-All Buffer Plus (Amersham Biosciences, Roosendaal, The Netherlands). Both strands were translated in a digoxigenin (DIG)-labelled RNA probe according to manufacturer's instructions (Roche Diagnostics $\mathrm{GmbH}$ ). The concentration of the DIG-labelled sense and antisense RNA probes were determined on a $1 \%$ agarose gel stained with ethidium bromide (Sigma, St Louis, MO, USA). Probes were stored at $-20{ }^{\circ} \mathrm{C}$ until further use.

\section{RNA in situ hybridisation}

The RNA in situ hybridisation (RISH) was performed as previously described (de Boer et al, 1998; de Boer et al, 2000). In short, $3 \mu \mathrm{m}$ thick paraffin sections were pre-treated and hybridised with $100 \mathrm{ng} \mathrm{ml}^{-1}$ DIG-labelled RNA probe diluted in hybridisation mixture containing $\mathrm{NaCl}$ and saline-sodium citrate (SSC; Table 2). Hybridisation was allowed for $16 \mathrm{~h}$ at either $55^{\circ} \mathrm{C}$ (IL-23p19) or $42^{\circ} \mathrm{C}$ ( $I L-12 p 35$ and $\left.I L-12 p 40\right)$ in a humidified chamber. Slides were washed $30 \mathrm{~min}$ in $2 \times$ SSC, followed by $45 \mathrm{~min}$ in $0.1 \times$ SSC with $20 \mathrm{~mm} \beta$-mercaptoethanol (Merck, Darmstadt, Germany), both used at hybridisation temperature (see Table 2). Subsequently, the slides were incubated for $30 \mathrm{~min}$ with $2 \mathrm{U} \mathrm{ml}^{-1}$ ribonuclease (RNase) T1 (Roche Diagnostics GmbH) in $2 \times \mathrm{SSC}$, $1 \mathrm{~mm}$ EDTA at $37^{\circ} \mathrm{C}$. RNA hybrids were detected using, subsequently, mouse anti-DIG $(1: 2000$, Sigma-Aldrich Chemie $\mathrm{GmbH}$, Steinham, Germany), rabbit anti-mouse Ig (1:50, DAKO, Glostrup, Denmark) and mouse alkaline phosphatase anti-alkaline phosphatase (APAAP, DAKO; Hazelbag et al, 2001).

\section{Immunohistochemistry}

Serial sections, $3-\mu \mathrm{m}$ thick, of formalin-fixed and paraffinembedded tissue were mounted on aminopropylethoxysilanecoated slides. Sections were deparaffinised, rehydrated and treated with $0.3 \% \mathrm{H}_{2} \mathrm{O}_{2}$ in methanol for $20 \mathrm{~min}$ to block endogenous peroxidase activity.

Antigen retrieval was performed $(0.01 \mathrm{~m}$ citrate, $\mathrm{pH}$ 6.0) and sections were rinsed in phosphate-buffered saline (PBS). Subsequently, sections were stained overnight using either a $1: 100$ dilution of an affinity-purified polyclonal goat anti-human IL-1 $\beta$ antibody (AF-201-NA; R\&D Systems, Minneapolis, MN, USA) or a $1: 300$ dilution of anti-human polyclonal rabbit anti-IL- 6 antibody (Abcam, Cambridge, UK). For anti-IL-1, the slides were incubated with a goat HRP-polymer kit (Biocare Medical, Concord, CA, USA) according to the manufacturer's instructions. For anti-IL-6, the slides were incubated with a biotinylated swine anti-rabbit antibody $(1: 200 ; \mathrm{DAKO})$ and subsequently incubated with a biotinylated horseradish peroxidase - streptavidin complex ( $1: 100$, DAKO), respectively. Immune complexes were visualised with diaminobenzidine as previously described (de Boer et al, 2000).

\section{(Semi-)quantitative evaluation of RISH and immunohistochemistry}

RISH was scored as previously described (Ruiter et al, 1998). Intensity was scored as none (0), mild (1), moderate (2) or intense (3) at low magnification $(\times 100)$. Furthermore, the percentage of positive tumour cells was determined and divided in 6 groups: $0 \%$ ( 0 , absent), $1-5 \%$ (1, sporadic), $6-25 \%$ (2, local), $26-50 \%$ (3, occasional), $51-75 \%$ (4, majority) and 76-100\% (5, large majority). 
Table 2 RNA probes used and RNA-in situ hybridisation conditions

\begin{tabular}{|c|c|c|c|c|c|c|}
\hline Target & Primer & Sequence $\left(5^{\prime}-3^{\prime}\right)$ & Product (bp) & Accession number & Position & Hybr. temp. $\left({ }^{\circ}\right)$ \\
\hline IL-1 $2 p 40$ & $\begin{array}{l}\text { Forward } \\
\text { Reverse }\end{array}$ & $\begin{array}{l}\text { GGACCAGAGCAGTGAGGTCTT } \\
\text { CTCCTTTTGTCCCСTCTGA }\end{array}$ & 373 & XM_0040II & |89-56| & 42 \\
\hline
\end{tabular}

Abbreviation: Hybr. temp. = hybridisation temperature.

The sum of both the percentage and the staining intensity of the positive cells resulted in an overall score ( 0 or 2 to 8$)$. The scores were combined into three groups: category 0 (score 0 , no expression), category 1 (scores 2, 3, 4 and 5, low expression) and category 2 (scores 6, 7 and 8, high expression). mRNA expression was scored by two independent researchers without knowing the identity and clinical outcome of the patients. The IL-1-positive cells and IL-6-positive cells were quantified in the tumour by counting the number of stained cells per six, randomly selected, high-power field of view $(\mathrm{HPF}, \times 400)$.

\section{Statistical analysis}

Data from immunohistochemistry as well as RISH are given as the mean \pm s.d. Statistical analysis was done using SPSS 17.0 (SPSS Inc., Chicago, IL, USA). Data were processed by using the $\chi^{2}$-test. Kaplan-Meier survival curves were generated to assess differences in disease-free period (defined as the observation time in months from surgery to relapse of the disease (disease-free survival)) or cumulative disease-specific survival (defined as time in months from surgery to death due to cervical cancer). A Cox regression was used for multivariate survival analysis. A value of $P<0.05$ was considered statistically significant.

\section{RESULTS}

\section{Patients}

Of the group of 90 patients, 68 patients were diagnosed as FIGO stage IB and 21 patients as FIGO stage IIA, and all underwent radical hysterectomy combined with pelvic lymph adenectomy (Table 1). Forty-seven patients received post-operative radiotherapy because of either tumour-positive lymph nodes or meeting the terms of the Sedlis criteria (Sedlis et al, 1999; a combination of two of the following unfavourable prognostic parameters: depth of infiltration $\geqslant 15 \mathrm{~mm}$, tumour size $\geqslant 40 \mathrm{~mm}$ and presence of vasoinvasion). Twenty-five patients suffered recurrent disease. At the end of the study, 70 patients were alive, 7 suffered from a recurrence and 18 patients had died of disease.

\section{Expression of $I L-23 p 19, I L-12 p 35$ and $I L-12 p 40$ in cervical cancer}

As IL-12p40 is both a subunit of IL-12 and IL-23, we have determined the expression of $I L-23 p 19$. Both $I L-23 p 19$ and $I L-12 p 40$ were expressed by cervical tumour cells (Figure $1 \mathrm{~A}$ and $C$ ). The expression of $I L-12 p 40$ was stronger than the expression of $I L-23 p 19$. IL-23p19 was expressed in $63 \%$ of the samples $(n=54), I L-12 p 40$ was expressed in $54 \%$ of the samples $(n=90)$ and $I L-12 p 35$ was expressed in $84 \%$ of the samples $(n=90$; Table 3$)$. All samples that expressed either $I L-23 p 19$ or $I L-12 p 40$ also expressed $I L-12 p 35 m R N A$. In contrast, 13 out of 44 samples that expressed $I L-12 p 40$ did not express $I L-23 p 19$.
A positive correlation between $I L-23 p 19$ and $I L-12 p 40$ was found ( $n=54, r^{2}=0.117, P=0.011$; data not shown). No statistically significant correlation between $I L-23 p 19$ and $I L-12 p 35$ was found ( $n=54, r^{2}=0.061, P=0.072$; data not shown).

\section{Association between $I L-23 p 19, I L-12 p 35$ and $I L-12 p 40$, and disease-specific survival in cervical cancer}

To investigate the relationship between the expression of $I L$ 23p19, IL-12p35 and IL-12p40, and disease-specific survival, Kaplan-Meier plots were created. A log-rank test was used to determine statistical differences in disease-specific survival. As the absence of $I L-12 p 40$ will result in neither IL-12 nor IL-23, we first confirmed that expression of $I L-12 p 40$ was associated with poor disease-specific survival (Figure $2 \mathrm{~A} ; n=48$, log-rank test 5.753, $P=0.017)$ in this cohort. The expression of $I L-12 p 35$ (Figure 2B; $n=74$, log-rank test $0.2019, P=0.653$ ) and the expression of $I L-23 p 19$ (Figure 2C; $n=33$, log-rank test 1.930, $P=0.165)$ were both not significantly associated with diseasespecific survival. The expression of $I L-23 p 19, I L-12 p 35$ or $I L-12 p 40$ showed no significant difference in disease-free survival (data not shown).

\section{Presence of IL-6-positive cells and association with disease-specific survival in cervical cancer}

The presence of $I L-23 p 19$ suggests that IL-23 may sustain a Th17positive cell population in cervical cancer. As differentiation towards the IL-17/IL-23 pathway is thought to occur in the presence of IL-1 and IL-6 in humans (Acosta-Rodriguez et al, 2007), we have determined the presence of IL-1 and IL-6-positive cells, using immunohistochemistry. Interleukin-1 was predominantly expressed by cells in the stromal compartment. Occasionally, tumour cells also showed weak IL-1 expression. No statistically significant association between low or high number of IL-1-expressing cells and disease-specific survival was observed (Figure 3A). Interleukin-6 was expressed by both cells in the epithelial (tumour cell) compartment and cells in the stromal compartment (Figure 1E). No significant association was observed between low or high IL-6 expression of cells in the epithelial compartment and disease-specific survival (Figure 1F). Subsequently, we quantified the number of IL-6-positive cells in the stroma. The presence of a high number of IL- 6 stromal positive cells (median 17 IL-6-positive cells/HPF) significantly associated with disease-specific survival (Figure $3 \mathrm{~B} ; n=83$, log-rank test $12.57, P<0.001)$. No statistical significant difference was observed for disease-free survival (data not shown). We also determined whether disease-specific survival was associated with the presence of both a high number of IL-6-positive stromal cells and low $I L$ $12 p 40$. In this latter case, an even stronger decrease in diseasespecific survival was observed (Figure $3 \mathrm{C} ; n=47$, log-rank test 20.38, $P<0.001)$. 

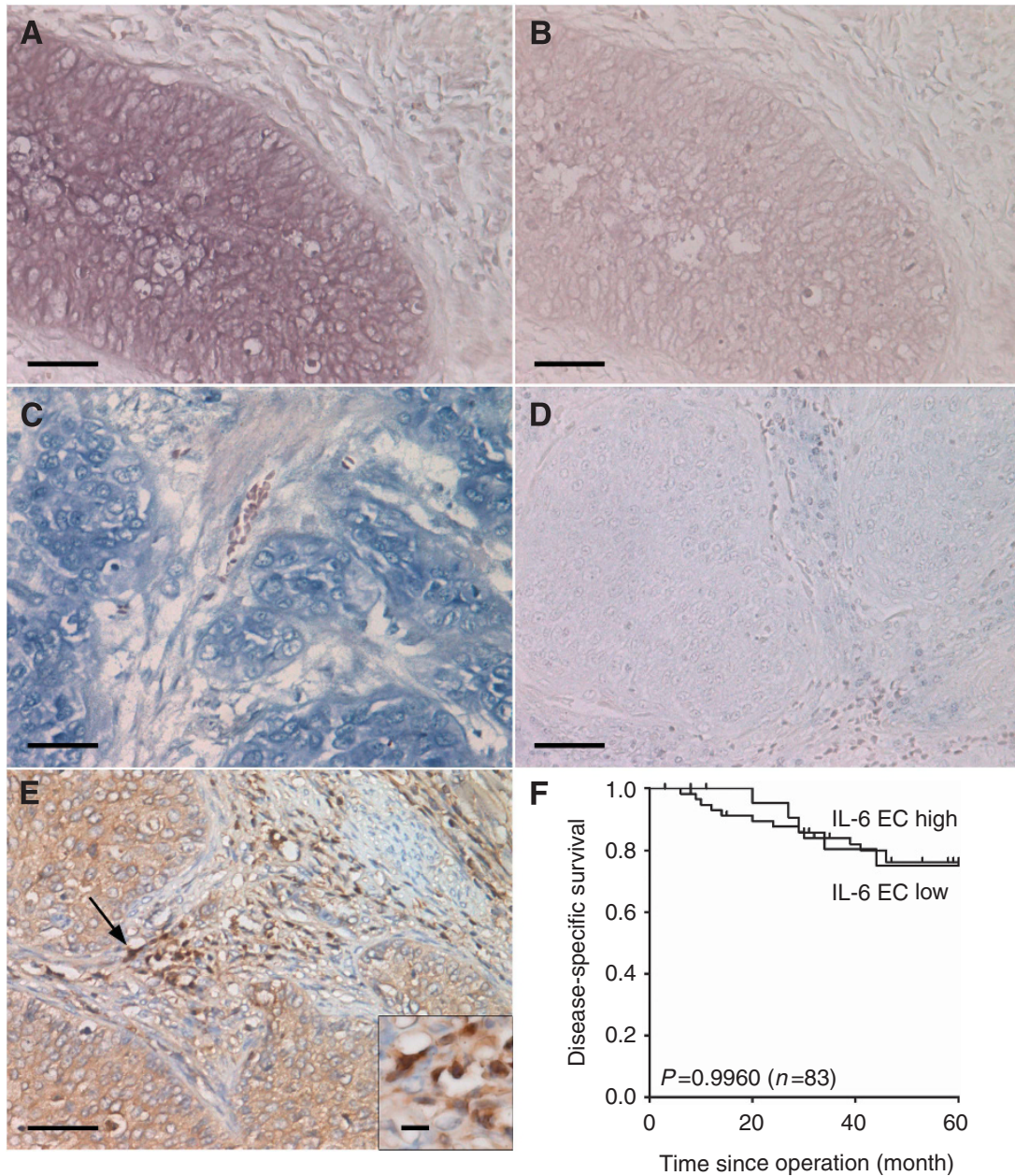

Figure I The expression of IL-23p/9, IL-I $2 p 40$ and IL-6. The expression of IL-23p/ 9 and IL-I $2 p 40$ were determined using RISH, and the expression of IL-6 was determined using immunohistochemistry as described in the Materials and Methods ( $\times 250$ magnification). (A) Cervical tumour, IL-23p/9 RISH. Tumour cells stain positive (moderate) for IL-23p /9; (B) negative (sense) control of IL-23p/9 RISH; (C) cervical tumour, IL- I 2p40 RISH. Tumour cells stain positive (strong) for IL-I2p40; (D) negative (sense) control of IL-12p40 RISH. (E) IL-6 staining of cervical cancer tissue. Both cells in the epithelial compartment (EC) as well as cells in the stroma express IL-6. Arrow indicates positive stromal cells. Detail ( $\times 400$ magnification) of IL-6-positive cells in the stroma; and (F) association between cells in the epithelial compartment wit low (IL-6 EC low) and high IL-6 (IL-6 EC high) expression and disease-specific survival. Bars correspond to $50 \mu \mathrm{m}$ in A-E and to $10 \mu \mathrm{m}$ in the inset of $\mathbf{E}$. No significant association between low or high IL-6 expression of the epithelial cells with disease-specific survival was observed.

\section{Association between low $I L-12 p 40$ expression, high number of IL-6-positive stromal cells and clinicopathological parameters}

To determine the relevance of our findings, we associated our immunological findings with clinicopathological parameters. First, a univariate Cox analysis was performed, using the clinical parameters, Sedlis criteria (two out of three of the following criteria positive: tumour size $\geqslant 40 \mathrm{~mm}$, vasoinvasion and deep stromal invasion), lymph node metastasis and parametrial involvement and the immunological parameters, low $I L-12 p 40$ expression, high number of IL-6-positive cells and high number of IL-6-positive cells, plus low $I L-12 p 40$ expression. In the univariate Cox analyses, all the included parameters showed a significantly increased hazard ratio (HR; Table 4). Subsequently, a multivariate Cox analysis with the three clinicopathological parameters and each of the significantly immunological parameters was performed. In this case, two of the three immunological parameters, high number of IL-6-positive stromal cells $(P=0.009$; HR, 7.447) and high number of IL-6-positive stromal cells and low IL-12p40 expression $(P=0.007$; HR, 20.123) were shown to be independent predictors of poor disease-specific survival.

\section{DISCUSSION}

In a previous study, we found an association between low expression of $I L-12 p 40$ and poor disease-specific survival, whereas high expression of $I L-12 p 40$ or lack of expression of $I L-12 p 40$ were associated with a favourable disease-specific survival (Zijlmans et al, 2007). As IL-12p40 combines with both IL-12p35 and IL$23 \mathrm{p} 19$, to form IL-12 and IL-23, respectively, in the present study, we have further investigated the role of $I L-12 p 40$ in cervical cancer.

Both $I L-23 p 19$ and $I L-12 p 35$ were expressed in the majority of the samples. Out of the 44 samples that expressed $I L-12 p 40,13$ samples did not express $I L-23 p 19$. As $I L-12 p 35$ expression seems to be ubiquitous in cervical cancer (Zijlmans et al, 2007), the level of $I L-12 p 40$ or $I L-23 p 19$ expression most probably determines whether IL-12, IL-23 or both are expressed. In our study, we observed a trend $(P=0.061 ; n=54)$ between $I L-23 p 19$ or $I L-12-p 35$ expression, whereas in the study of Wolf et al (2010) in ovarian cancer $(n=112)$ a significant correlation between the expression of $I L-23 p 19$ and $I L-12 p 35$ was found. The discrepancy between our results and the results of Wolf et al (2010) may be due to the smaller size of our study group. Very few studies have investigated the association between local expression of IL-12 or IL-23, and 
prognosis. Using immmunohistochemistry, IL-12 has been associated with improved survival in patients with (advanced) gastric carcinoma (Ye et al, 2007; Nagashima et al, 2008). In the study of Wolf et al (2010), using RT-PCR, both $I L-12 p 35$ and $I L-23-p 19$ were associated with a superior outcome. In a multivariate analysis, $I L-12 p 35$ was found to be an independent factor for overall survival of ovarian carcinoma. As stated previously, we have observed a statistically significant association between low expression of $I L$ $12 p 40$ and poor disease-specific survival in cervical carcinoma (Zijlmans et al, 2007). In the present study and our previous study (Zijlmans et al, 2007), we did not find a significant association between either $I L-23 p 19$ or $I L-12 p 35$ expression and diseasespecific survival. As $I L-23 p 19$ and $I L-12 p 35$ are both expressed, it is important to determine which cytokine, IL-23 or IL-12, has a dominant effect on the tumour microenvironment.

The molecular interaction between IL-23p19 and IL-12p40 has been studied by Beyer et al (2008). These authors reported that the

Table 3 Correlation between IL-23p/9, IL-12p35 and IL-12p40 expression in cervical carcinoma.

\begin{tabular}{|c|c|c|c|c|c|}
\hline \multirow[b]{2}{*}{ Cytokine } & \multirow[b]{2}{*}{$\begin{array}{l}\text { Expression } \\
\text { level }\end{array}$} & \multicolumn{4}{|c|}{ IL-I 2 p35 } \\
\hline & & Absent & Low & High & $\begin{array}{c}\text { Total } \\
n(\%)^{\mathrm{a}}\end{array}$ \\
\hline \multirow[t]{3}{*}{$1 L-12 p 40$} & Absent & 14 & 21 & 6 & $41(46)$ \\
\hline & Low & 0 & 14 & 14 & $28(3 \mid)$ \\
\hline & High & 0 & 3 & 18 & $21(23)$ \\
\hline \multirow{2}{*}{$\begin{array}{l}\text { Total } \\
P \text {-value }\end{array}$} & $n(\%)^{\mathrm{a}}$ & $14(16)$ & $38(42)$ & $38(42)$ & $90(100)$ \\
\hline & & \multicolumn{4}{|c|}{ IL-23p/9 } \\
\hline \multirow[t]{3}{*}{ IL-12p40 } & Absent & 7 & I & 2 & $10(19)$ \\
\hline & Low & 8 & 5 & II & $24(44)$ \\
\hline & High & 5 & 4 & 11 & $20(37)$ \\
\hline \multirow{2}{*}{$\begin{array}{l}\text { Total } \\
P \text {-value }\end{array}$} & $n(\%)^{a}$ & $20(37)$ & $10(19)$ & $24(44)$ & $54(100)$ \\
\hline & & \multicolumn{4}{|c|}{ IL-23p/9 } \\
\hline \multirow[t]{3}{*}{$1 L-12 p 35$} & Absent & I & 0 & 0 & I (2) \\
\hline & Low & 8 & 5 & 8 & $21(39)$ \\
\hline & High & 11 & 5 & 16 & $32(59)$ \\
\hline $\begin{array}{l}\text { Total } \\
P \text {-value }\end{array}$ & $n(\%)^{a}$ & $20(37)$ & $10(19)$ & $24(44)$ & $\begin{array}{c}54(100) \\
0.619\end{array}$ \\
\hline
\end{tabular}

$a_{n}=$ number of tumours. The scores were combined into three groups: absent expression, low expression and high expression as described in Materials and Methods. Statistically significant $P$-value is given in bold. interface region of IL-23p19 and IL-12p35 on IL-12p40 overlap. Because of different interresidue interactions of IL-12p35 and IL23 p19 with IL-12p40, these molecules interact with a different affinity with IL-12p40. Therefore, the availability of IL-12p40 in combination with the affinity for IL-12p35 and IL-23-p19 may result in skewing of the IL-12/IL-23 response. This is supported by experiments performed by Zwiers et al (2011). These authors showed that in an experimental animal model, polymorphic variants of IL-12p40 can skew IL-12/IL-23 synthesis (Zwiers et al, 2011). Thus, both differences in protein interactions between IL-23p19 and IL-12p35 on the one hand and IL-12p40 on the other hand, and genetic polymorphisms in the protein chains, such as IL-12p 40 , contribute to the amounts of IL-12 and IL-23 formed. Our results support a previously suggested immunosuppressive role for IL-23 (Langowski et al, 2006). This is further supported by a study in ovarian carcinoma where genetic differences in the IL-23 receptor have been reported to influence prognosis (Zhang et al, 2010).

In contrast, it has also been shown that overexpression of IL-23 reduces tumour growth and metastasis formation, and that IL-23 is able to elicit a strong cytotoxic T-cell memory response (Lo et al, 2003; Shan et al, 2006), underscoring our view that the level of expression of the different cytokines and chemokines has an import role in the final outcome.

Our data suggest that in the presence of a limited amount of $I L-12 p 40$ the biological effect of IL-23 dominates, whereas in the presence of a high amount of $I L-12 p 40$ the biological effect of IL-12 prevails. As IL-12 polarises the immune response towards an antiviral response, (Trinchieri, 1994) the favourable cumulative overall survival of patients with a high IL-12-positive cell density (Ye et al, 2007; Nagashima et al, 2008) and high expression level of $I L-12 p 35$ (Wolf et al, 2010) and IL-12p40 (Zijlmans et al, 2007) can be explained by the capacity of this cytokine to increase the lytic activity and the production of interferon- $\gamma$ of natural killer cells and cytotoxic T lymphocytes (Trinchieri, 1994). Interestingly, we previously observed an association between high expression of $I L-$ $12 p 40$ and high expression of TGF- $\beta(P=0.024$; Zijlmans et al, 2007 ), suggesting that the tumour cells are selected to counter act the effect of IL-12 or skew the response to the IL-17/IL-23 pathway.

In humans, in addition to IL-1, IL- 6 and TGF- $\beta$ have been implicated to have a role in the IL-17/IL-23 pathway (Veldhoen et al, 2006; Acosta-Rodriguez et al, 2007). Previously, we have shown that it is likely that activated TGF- $\beta$ is present in the tumour microenvironment, as PAI-1, a target gene of TGF- $\beta$, is expressed and expression of PAI-1 is associated with survival (Hazelbag et al, 2004). Furthermore, both the integrin av $\beta 6$ and active matrix metalloproteinase-2, known to activate TGF- $\beta$, are associated with poor disease-specific survival (Sier et al, 2006; Hazelbag et al,
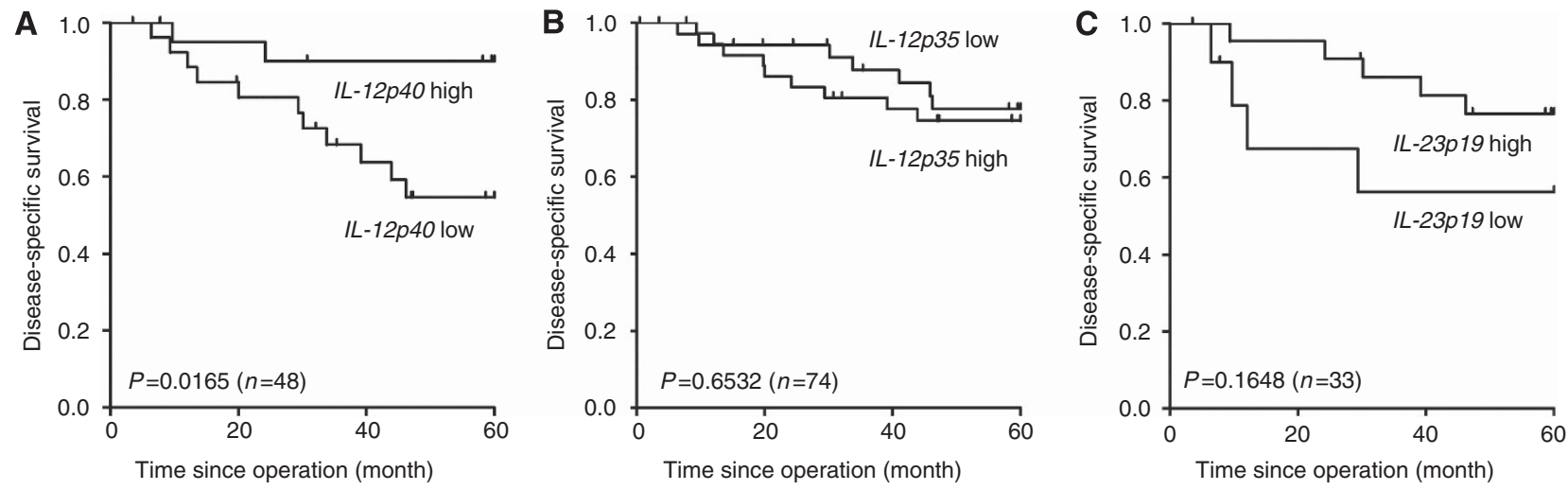

Figure 2 Association between IL-I2p40 (A), IL-I 2p35 (B) and IL-23p/9 (C) expression and disease-specific survival in cervical carcinoma. IL-23p/9, IL-I 2p35 and IL-I 2p40 were determined by RISH as described in the Materials and Methods. 

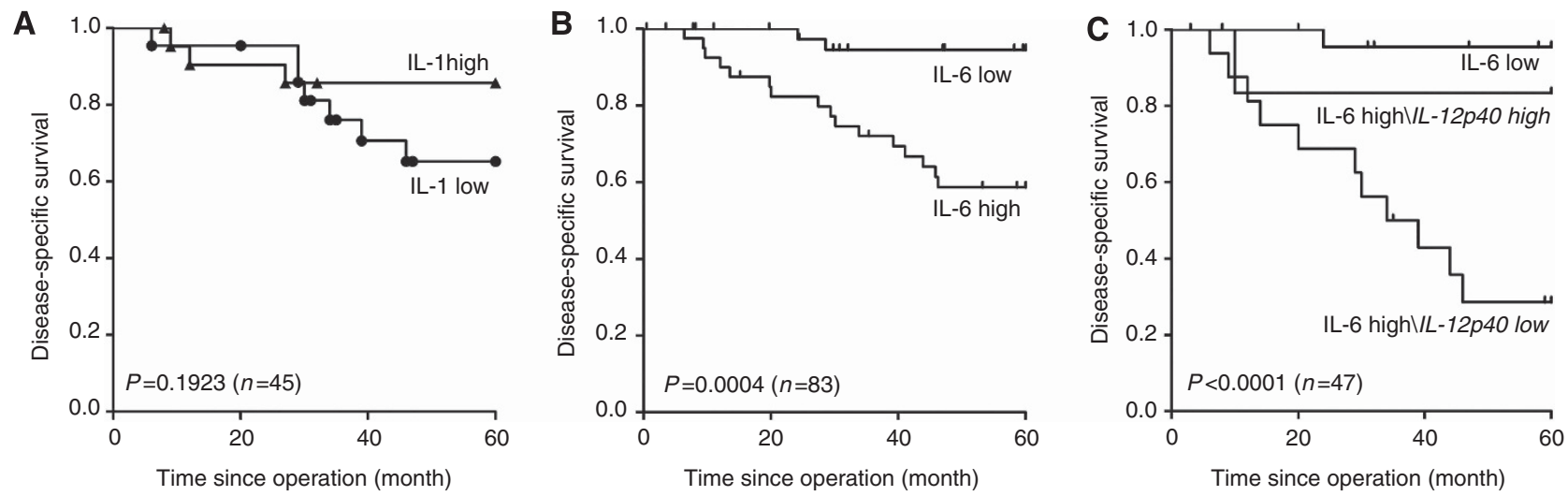

Figure 3 Association between high number of IL-I-positive cells (A), high number of IL-6-positive stromal cells (B) and IL-I2p40 expression in combination with high number of IL-6- positive stromal cells $(\mathbf{C})$ and disease-specific survival. The IL-I and IL-6 expression were determined by immunohistochemistry as described in Materials and Methods. IL-I 2p40 was determined by RISH as described in the Materials and Methods.

Table 4 Cox regression of clinicopathological variables and IL-I 2p40 and the number of IL-6-positive cells in cervical carcinoma

\begin{tabular}{lccc}
\hline Univariate & Hazard ratio & $\mathbf{9 5 \%} \mathbf{C l}$ & P-value \\
\hline Sedlis positive & 4.354 & $1.608-11.789$ & $\mathbf{0 . 0 0 4}$ \\
Lymph node metastasis & 3.266 & $1.286-8.296$ & $\mathbf{0 . 0 1 3}$ \\
Parametrial involvement & 3.645 & $1.411-9.41$ I & $\mathbf{0 . 0 0 8}$ \\
Low IL-I2p40 & $5.23 \mid$ & $1.156-23.66 \mid$ & $\mathbf{0 . 0 3 2}$ \\
High number of IL-6 cells & 8.975 & $2.063-39.05 \mid$ & $\mathbf{0 . 0 0 3}$ \\
Low number of IL-6 cells & Reference & & \\
High number of IL-6 cells/low & 21.832 & $2.805-169.915$ & $\mathbf{0 . 0 0 3}$ \\
IL-I2p40 & & & \\
Multivariate & & & \\
Sedlis positive & 3.848 & $1.270-11.663$ & $\mathbf{0 . 0 1 7}$ \\
Lymph node metastasis & 1.333 & $0.439-4.052$ & 0.612 \\
Parametrial involvement & 1.526 & $0.542-4.444$ & 0.438 \\
High number of IL-6 cells & 7.447 & $1.659-33.432$ & $\mathbf{0 . 0 0 9}$ \\
& & & \\
Multivariate & & & \\
Sedlis positive & 0.706 & $0.150-3.310$ & 0.659 \\
Lymph node metastasis & 2.887 & $0.836-9.965$ & 0.094 \\
Parametrial involvement & 1.168 & $0.283-4.822$ & 0.830 \\
Low number of IL-6 cells & Reference & & \\
High number of IL-6 & 20.123 & $2.248-180.147$ & $\mathbf{0 . 0 0 7}$ \\
cells/low IL-I2p40 & & & \\
\hline
\end{tabular}

Abbreviation: $\mathrm{Cl}=$ confidence interval. Shown are the log-rank test and $P$-value of compared expression levels. Statistically significant $P$-values are given in bold.

2007). Even though the role of TGF- $\beta$ in inducing Th17 in humans has been questioned, TGF- $\beta$ may suppress Th1 and Th2 development, thus favoring Th17 development (Santarlasci et al, 2009; Das et al, 2009).

In our study, low or high numbers of IL-1-positive cells were not associated with disease-specific survival. The presence of a high number of IL-6-expressing stromal cells was significantly associated with poor disease-specific survival $(P<0.001)$. Previously,
IL-6 has been implicated as an autocrine or paracrine growth factor for cervical cancer (Tartour et al, 1994; Castrilli et al, 1997). Interleukin-6 has been shown to induce VEGF transcription via the STAT3 signalling pathway, thus promoting an angiogenic switch (Wei et al, 2003). Indeed, blockade of the IL-6 receptor on cervical cancer cell lines was shown to interfere with cell survival signals and blocked the expression of VEGF (Su et al, 2005).

As HPV vaccines will become available for the treatment of metastasised cervical carcinoma, the local cytokine/chemokine profile may be important to discriminate patients with a beneficial immune response from non-responding patients.

In conclusion, $I L-12 p 40$ has at least a dual role in cervical carcinoma by associating with both $I L-23 p 19$ and $I L-12 p 35$. We have shown that low $I L-12 p 40$ expression was significantly associated with poor disease-specific survival $(P=0.017)$. Also, a high number of stromal IL-6-producing cells was shown to associate with poor disease-specific survival $(P<0.001)$. The worst disease-specific survival was observed in a subgroup of patients that displayed a high number of stromal IL-6-expressing cells and low $I L-12 p 40$ expression $(P<0.001)$. Furthermore, both a high number of stromal IL-6-expressing cells and a high number of stromal IL-6, plus $I L-12 p 40$ expression, were shown to be independent clinicopathological parameters compared with lymph node metastasis, parametrial involvement and Sedlis score ( $P=0.009$ and $P=0.022$, respectively). Our results with IL-6 and $I L-12 p 40$ are in accordance with the hypothesis that the IL-17/IL-23 pathway has a suppressive role in cervical cancer.

\section{ACKNOWLEDGEMENTS}

We thank Enno J Dreef, Natalja T ter Haar, Sandra M KolkmanUljee, Nils I Wijtzes and Michel C Verboom for their technical assistance in the Department of Pathology.

\section{Conflict of interest}

The authors declare no conflict of interest.

\section{REFERENCES}

Acosta-Rodriguez EV, Napolitani G, Lanzavecchia A, Sallusto F (2007) Interleukins 1beta and 6 but not transforming growth factor-beta are essential for the differentiation of interleukin 17-producing human $\mathrm{T}$ helper cells. Nat Immunol 8(9): 942-949
Balkwill F (2003) Chemokine biology in cancer. Semin Immunol 15(1): 49-55

Beyer BM, Ingram R, Ramanathan L, Reichert P, Le HV, Madison V, Orth P (2008) Crystal structures of the pro-inflammatory cytokine 
interleukin-23 and its complex with a high-affinity neutralizing antibody. J Mol Biol 382(4): 942-955

Castrilli G, Tatone D, Diodoro MG, Rosini S, Piantelli M, Musiani P (1997) Interleukin 1alpha and interleukin 6 promote the in vitro growth of both normal and neoplastic human cervical epithelial cells. Br J Cancer 75(6): 855-859

Clerici M, Merola M, Ferrario E, Trabattoni D, Villa ML, Stefanon B, Venzon DJ, Shearer GM, De Palo G, Clerici E (1997) Cytokine production patterns in cervical intraepithelial neoplasia: association with human papillomavirus infection. J Natl Cancer Inst 89(3): 245-250

Coussens LM, Werb Z (2002) Inflammation and cancer. Nature 420(6917): 860-867

Das J, Ren G, Zhang L, Roberts AI, Zhao X, Bothwell AL, Van KL, Shi Y, Das G (2009) Transforming growth factor beta is dispensable for the molecular orchestration of Th17 cell differentiation. J Exp Med 206(11): 2407-2416

de Boer WI, Sont JK, van Schadewijk A, Stolk J, van Krieken JH, Hiemstra PS (2000) Monocyte chemoattractant protein 1, interleukin 8, and chronic airways inflammation in COPD. J Pathol 190(5): 619-626

de Boer WI, van Schadewijk A, Sont JK, Sharma HS, Stolk J, Hiemstra PS, van Krieken JH (1998) Transforming growth factor betal and recruitment of macrophages and mast cells in airways in chronic obstructive pulmonary disease. Am J Respir Crit Care Med 158(6): 1951-1957

Elgert KD, Alleva DG, Mullins DW (1998) Tumor-induced immune dysfunction: the macrophage connection. J Leukoc Biol 64(3): 275-290

Hazelbag S, Fleuren GJ, Baelde JJ, Schuuring E, Kenter GG, Gorter A (2001) Cytokine profile of cervical cancer cells. Gynecol Oncol 83(2): 235-243

Hazelbag S, Kenter G, Gorter A, Dreef E, Koopman L, Violette S, Weinreb P, Fleuren G (2007) Overexpression of the alphavbeta6 integrin in cervical squamous cell carcinoma is a prognostic factor for decreased survival. J Pathol 212(3): 316-324

Hazelbag S, Kenter GG, Gorter A, Fleuren GJ (2004) Prognostic relevance of TGF-betal and PAI-1 in cervical cancer. Int J Cancer 112(6): 1020-1028

Korn T, Bettelli E, Oukka M, Kuchroo VK (2009) IL-17 and Th17 Cells. Annu Rev Immunol 27: 485-517

Kusmartsev S, Gabrilovich DI (2002) Immature myeloid cells and cancerassociated immune suppression. Cancer Immunol Immunother 51(6): 293-298

Langowski JL, Zhang X, Wu L, Mattson JD, Chen T, Smith K, Basham B, McClanahan T, Kastelein RA, Oft M (2006) IL-23 promotes tumour incidence and growth. Nature 442(7101): 461-465

Lo CH, Lee SC, Wu PY, Pan WY, Su J, Cheng CW, Roffler SR, Chiang BL, Lee CN, Wu CW, Tao MH (2003) Antitumor and antimetastatic activity of IL-23. J Immunol 171(2): 600-607

Manna PP, Mohanakumar T (2002) Human dendritic cell mediated cytotoxicity against breast carcinoma cells in vitro. J Leukoc Biol 72(2): $312-320$

Munoz N (2000) Human papillomavirus and cancer: the epidemiological evidence. J Clin Virol 19(1-2): 1-5

Nagashima N, Nakayama Y, Inoue Y, Nagata J, Matsumoto K, Minagawa N, Katsuki T, Shibao K, Hirata K, Sako T, Hamada T, Nagata N (2008) Prognostic significance of the local expression of interleukin-12 in patients with advanced gastric cancer. Anticancer Res 28(2B): 1277-1283

Rock CL, Michael CW, Reynolds RK, Ruffin MT (2000) Prevention of cervix cancer. Crit Rev Oncol Hematol 33(3): 169-185

Ruiter DJ, Ferrier CM, van Muijen GN, Henzen-Logmans SC, Kennedy S, Kramer MD, Nielsen BS, Schmitt M (1998) Quality control of immunohistochemical evaluation of tumour-associated plasminogen activators and related components. European BIOMED-1 Concerted Action on Clinical Relevance of Proteases in Tumour Invasion and Metastasis. Eur J Cancer 34(9): 1334-1340

Santarlasci V, Maggi L, Capone M, Frosali F, Querci V, De PR, Liotta F, Cosmi L, Maggi E, Romagnani S, Annunziato F (2009) TGF-beta indirectly favors the development of human Th17 cells by inhibiting Th1 cells. Eur J Immunol 39(1): 207-215

Schwartz SM, Daling JR, Shera KA, Madeleine MM, McKnight B, Galloway DA, Porter PL, McDougall JK (2001) Human papillomavirus and prognosis of invasive cervical cancer: a population-based study. J Clin Oncol 19(7): 1906-1915

Sedlis A, Bundy BN, Rotman MZ, Lentz SS, Muderspach LI, Zaino RJ (1999) A randomized trial of pelvic radiation therapy $v s$ no further therapy in selected patients with stage IB carcinoma of the cervix after radical hysterectomy and pelvic lymphadenectomy: A Gynecologic Oncology Group Study. Gynecol Oncol 73(2): 177-183

Shan BE, Hao JS, Li QX, Tagawa M (2006) Antitumor activity and immune enhancement of murine interleukin-23 expressed in murine colon carcinoma cells. Cell Mol Immunol 3(1): 47-52

Sier CF, Zuidwijk K, Zijlmans HJ, Hanemaaijer R, Mulder-Stapel AA, Prins FA, Dreef EJ, Kenter GG, Fleuren GJ, Gorter A (2006) EMMPRIN-induced MMP-2 activation cascade in human cervical squamous cell carcinoma. Int J Cancer 118(12): 2991-2998

Strobl H (2003) Molecular mechanisms of dendritic cell sublineage development from human hematopoietic progenitor/stem cells. Int Arch Allergy Immunol 131(2): 73-79

$\mathrm{Su}$ JL, Lai KP, Chen CA, Yang CY, Chen PS, Chang CC, Chou CH, Hu CL, Kuo ML, Hsieh CY, Wei LH (2005) A novel peptide specifically binding to interleukin-6 receptor (gp80) inhibits angiogenesis and tumor growth. Cancer Res 65(11): 4827-4835

Tartour E, Gey A, Sastre-Garau X, Pannetier C, Mosseri V, Kourilsky P, Fridman WH (1994) Analysis of interleukin 6 gene expression in cervical neoplasia using a quantitative polymerase chain reaction assay: evidence for enhanced interleukin 6 gene expression in invasive carcinoma. Cancer Res 54(23): 6243-6248

Trinchieri G (1994) Interleukin-12: a cytokine produced by antigenpresenting cells with immunoregulatory functions in the generation of T-helper cells type 1 and cytotoxic lymphocytes. Blood 84(12): 4008-4027

Trinchieri G (2003) Interleukin-12 and the regulation of innate resistance and adaptive immunity. Nat Rev Immunol 3(2): 133-146

Veldhoen M, Hocking RJ, Atkins CJ, Locksley RM, Stockinger B (2006) TGFbeta in the context of an inflammatory cytokine milieu supports de novo differentiation of IL-17-producing T cells. Immunity 24(2): 179-189

Vicari AP, Treilleux I, Lebecque S (2004) Regulation of the trafficking of tumour-infiltrating dendritic cells by chemokines. Semin Cancer Biol 14(3): 161-169

Waggoner SE (2003) Cervical cancer. Lancet 361(9376): 2217-2225

Wei LH, Kuo ML, Chen CA, Chou CH, Lai KB, Lee CN, Hsieh CY (2003) Interleukin-6 promotes cervical tumor growth by VEGF-dependent angiogenesis via a STAT3 pathway. Oncogene 22(10): 1517-1527

Wolf AM, Rumpold H, Reimer D, Marth C, Zeimet AG, Wolf D (2010) High IL-12 p35 and IL-23 p19 mRNA expression is associated with superior outcome in ovarian cancer. Gynecol Oncol 118(3): 244-250

Xu M, Mizoguchi I, Morishima N, Chiba Y, Mizuguchi J, Yoshimoto T (2010) Regulation of antitumor immune responses by the IL-12 family cytokines, IL-12, IL-23, and IL-27. Clin Dev Immunol 2010: 832454

Ye ZB, Ma T, Li H, Jin XL, Xu HM (2007) Expression and significance of intratumoral interleukin-12 and interleukin-18 in human gastric carcinoma. World J Gastroenterol 13(11): 1747-1751

Zhang Z, Zhou B, Zhang J, Chen Y, Lai T, Yan L, Liang A, Li Y, Wang Y, Chen Y, Zhang L, Xi MR (2010) Association of interleukin-23 receptor gene polymorphisms with risk of ovarian cancer. Cancer Genet Cytogenet 196(2): 146-152

Zijlmans HJ, Fleuren GJ, Baelde HJ, Eilers PH, Kenter GG, Gorter A (2006) The absence of CCL2 expression in cervical carcinoma is associated with increased survival and loss of heterozygosity at 17q11.2. J Pathol 208(4): 507-517

Zijlmans HJ, Fleuren GJ, Baelde HJ, Eilers PH, Kenter GG, Gorter A (2007) Role of tumor-derived proinflammatory cytokines GM-CSF, TNF-alpha, and IL-12 in the migration and differentiation of antigen-presenting cells in cervical carcinoma. Cancer 109(3): 556-565

Zwiers A, Fuss IJ, Seegers D, Konijn T, Garcia-Vallejo JJ, Samsom JN, Strober W, Kraal G, Bouma G (2011) A polymorphism in the coding region of Il12b promotes IL-12p70 and IL-23 heterodimer formation. J Immunol 186(6): 3572-3580

This work is published under the standard license to publish agreement. After 12 months the work will become freely available and the license terms will switch to a Creative Commons Attribution-NonCommercial-Share Alike 3.0 Unported License. 